\title{
Optimization of process parameters for machining of Al 7075 thin-walled structures
}

\author{
Borojević, S. ${ }^{a}$, Lukić, D. ${ }^{b}$, Milošević, M. ${ }^{b}$, Vukman, J. ${ }^{b}$, Kramar, D. ${ }^{c, *}$ \\ ${ }^{a}$ University of Banjaluka, Faculty of Mechanical Engineering, Banja Luka, Bosnia and Herzegovina \\ bUniversity of Novi Sad, Faculty of Technical Sciences, Novi Sad, Serbia \\ 'University of Ljubljana, Faculty of Mechanical Engineering, Ljubljana, Slovenia
}

\begin{abstract}
A B S T R A C T
The aim of this paper was focused on research in order to improve the manufacturing of aluminium alloy thin-walled components through the optimization of milling process parameters. The methodology for optimization of milling parameters is developed and presented. The influence of the tool path strategy, wall thickness and feed rate on the machining time, dimensional accuracy deviation, shape and position accuracy deviation, and surface roughness in the case of line-type thin-walled parts machining were analysed. Based on the analysis of experimental results, the corresponding empirical models of responses were identified. Optimization of results was conducted using response surface methodology. Verification of optimization results was executed using two additional experiments. The results from experimental verification show a satisfactory matching with calculated optimal values. The basic scientific contribution of the paper relates to the development of a methodology for optimization of machining parameters for milling of thinwalled structures of aluminium alloy using an ANOVA method, Central Composite Design experiment and empirical modelling. Practical implications are related to the correct selection of the tool path strategy and feed rate value for machining of thin-walled aluminium components in order to achieve the required output techno-economic effects.
\end{abstract}

\author{
ARTICLE INFO \\ Keywords: \\ Thin-walled structures; \\ Aluminium alloy Al 7075; \\ Optimization; \\ Response surface methodology; \\ Machining process parameters; \\ Milling \\ *Corresponding author: \\ davorin.kramar@fs.uni-lj.si \\ (Kramar, D.) \\ Article history: \\ Received 26 March 2018 \\ Revised 28 May 2018 \\ Accepted 29 May 2018
}

\section{References}

[1] Jambor, A., Beyer, M. (1997). New cars - new materials, Materials \& Design, Vol. 18, No. 4-6, 203-209, doi: 10.1016/S0261-3069(97)00049-6.

[2] Hirsch, J., Al-Samman, T. (2013). Superior light metals by texture engineering: Optimized aluminium and magnesium alloys for automotive applications, Acta Materialia, Vol. 61, No. 3, 818-843, doi: 10.1016/j.actamat.2012. 10.044 .

[3] Smith, S., Dvorak, D. (1998). Tool path strategies for high speed milling aluminum workpieces with thin webs, Mechatronics, Vol. 8, No. 4, 291-300, doi: 10.1016/S0957-4158(97)00058-5.

[4] Pompa, M.G.R. (2010). Computer aided process planning for high-speed milling of thin-walled parts: Strategybased support, Ph.D. Thesis, University of Twente, Enschede, Netherlands, doi: 10.3990/1.9789036530408.

[5] Scippa, A., Grossi, N., Campatelli, G. (2014). FEM based cutting velocity selection for thin walled part machining, Procedia CIRP, Vol. 14, 287-292, doi: 10.1016/i.procir.2014.03.023.

[6] Huang, X., Sun, J., Li, J. (2015). Effect of initial residual stress and machining-induced residual stress on the deformation of aluminium alloy plate, Strojniški vestnik - Journal of Mechanical Engineering, Vol. 61, No. 2, 131-137, doi: $10.5545 /$ sv-jme.2014.1897.

[7] Kopač, J., Kržič, P. (2008). CAM algorithm as important element by achieving of good machined surface quality, Strojniški vestnik - Journal of Mechanical Engineering, Vol. 54, No. 4, 280-287. 
[8] Dai, B., Yu, G.-B., Guan, Y.-Q., Shao, J.-P., Guan, Y.-Q., Wu, X.-M., Liu, Y.-X. (2015). Machining surface quality analysis of aluminum alloy thin-walled parts in aerospace, International Journal of Security and Its Applications, Vol. 9, No. 11, 201-208, doi: 10.14257/ijsia.2015.9.11.19.

[9] Herranz, S., Campa, F.J., López de Lacalle, L.N., Rivero, A., Lamikiz, A., Ukar, E., Sánchez, J.A., Bravo, U. (2005). The milling of airframe components with low rigidity: A general approach to avoid static and dynamic problems, Proceedings of the Institution of Mechanical Engineers, Part B: Journal of Engineering Manufacture, Vol. 219, No. 11, 789-801, doi: 10.1243/095440505X32742.

[10] Zhou, X., Zhang, D., Luo, M., Wu, B. (2014). Toolpath dependent chatter suppression in multi-axis milling of hollow fan blades with ball-end cutter, The International Journal of Advanced Manufacturing Technology, Vol. 72, No. 5-8, 643-651, doi: 10.1007/s00170-014-5698-6.

[11] Rai, J.K., Xirouchakis, P. (2008). Finite element method based machining simulation environment for analyzing part errors induced during milling of thin-walled components, International Journal of Machine Tools and Manufacture, Vol. 48, No. 6, 629-643, doi: 10.1016/i.ijmachtools.2007.11.004.

[12] Aoyama, T., Kakinuma, Y. (2005). Development of fixure devices for thin and compliant workpieces, CIRP Annals, Vol. 54, No. 1, 325-328, doi: 10.1016/S0007-8506(07)60114-0.

[13] Izamshah, R., Mo, J.P.T., Ding, S. (2011). Hybrid deflection prediction on machining thin-wall monolithic aerospace components, Proceedings of the Institution of Mechanical Engineers, Part B: Journal of Engineering Manufacture, Vol. 226, No. 4, 592-605, doi: 10.1177/0954405411425443.

[14] Mwinuka, T.E., Mgwatu, M.I. (2015). Tool selection for rough and finish CNC milling operations based on toolpath generation and machining optimization, Advances in Production Engineering \& Management, Vol. 10, No. 1, 18-26, doi: 10.14743/apem2015.1.189.

[15] Lazarević, D., Nedić, B., Marušić, V., Mišić, M., Šarkoćević, Ž. (2017). Regenerating the NC code in order to improve the surface quality, Tehnički vjesnik - Technical Gazette, Vol. 24, No. 2, 355-362, doi: 10.17559/TV20161018122324.

[16] Kuczmaszewski, J., Pieśko, P., Zawada-Michałowska, M. (2017). Influence of milling strategies of thin-walled elements on effectiveness of their manufacturing, Procedia Engineering, Vol. 182, 381-386, doi: 10.1016/ j.proeng.2017.03.117.

[17] Novak-Marcincin, J., Janak, M., Novakova-Marcincinova, L., Fecova, V. (2012). Possibility of quick check on suitability of milling strategy, Tehnički vjesnik - Technical Gazette, Vol. 19, No. 4, 959-964.

[18] Pandian, P., Prabhu, R., Sakthimurugan, K. (2013). Surface error compensation in HSM of thin wall structures, International Journal of Engineering Science Invention, Vol. 2, No. 2, 1-11.

[19] Msaddek, E.B., Bouaziz, Z., Dessein, G., Baili, M. (2012). Optimization of pocket machining strategy in HSM, The International Journal of Advanced Manufacturing Technology, Vol. 62, No. 1-4, 69-81, doi: 10.1007/s00170-0113801-9.

[20] Denkena, B., Schmidt, C. (2007). Experimental investigation and simulation of machining thin-walled workpieces, Production Engineering, Research and Development, Vol. 1, No. 4, 343-350, doi: 10.1007/s11740-007-0017-9.

[21] Budak, E., Altintas, Y. (1995). Modeling and avoidance of static form errors in peripheral milling of plates, International Journal of Machine Tools and Manufacture, Vol.35, No.3, 459-476, doi: 10.1016/0890-6955(94)P2628-S.

[22] Baranek, I., Buransky, I., Peterka, J. (2013). Influence of material removal way on thin-walled part quality by milling, MM Science Journal, 414-417, doi: 10.17973/MMSJ.2013 06_201306.

[23] Rusinek, R., Zaleski, K. (2016). Dynamics of thin-walled element milling expressed by recurrence analysis, Meccanica, Vol. 51, No. 6, 1275-1286, doi: 10.1007/s11012-015-0293-y.

[24] Kanchana, J., Prabhu Raja, V., Prakash, R., Radhakrishnan, P. (2002). Dynamics of high-speed machining of aerospace structures using finite-element analysis, Defence Science Journal, Vol. 52, No. 4, 403-408.

[25] Arnaud, L., Gonzalo, O., Seguy, S., Jauregi, H., Peigné, G. (2011). Simulation of low rigidity part machining applied to thin-walled structures, The International Journal of Advanced Manufacturing Technology, Vol. 54, No. 5-8, 479488, doi: $10.1007 / \mathrm{s} 00170-010-2976-9$.

[26] Masmali, M., Mathew, P. (2017). An analytical approach for machining thin-walled workpieces, Procedia CIRP, Vol. 58, 187-192, doi: 10.1016/j.procir.2017.03.186.

[27] Pare, V., Agnihotri, G., Krishna, C. (2015). Selection of optimum process parameters in high speed CNC endmilling of composite materials using meta heuristic techniques - A comparative study, Strojniški vestnik - Journal of Mechanical Engineering, Vol. 61, No. 3, 176-186, doi: 10.5545/sv-jme.2014.1914.

[28] Ratchev, S., Nikov, S., Moualek, I. (2004). Material removal simulation of peripheral milling of thin wall lowrigidity structures using FEA, Advances in Engineering Software, Vol. 35, No. 8-9, 481-491, doi: 10.1016/ j.advengsoft.2004.06.011.

[29] Bose, G.K., Mahapatra, K.K. (2014). Parametric study of die sinking EDM process on AISI H13 tool steel using statistical techniques, Advances in Production Engineering \& Management, Vol. 9, No. 4, 168-180, doi: 10.14743/ apem2014.4.185.

[30] Raja, I.R.A. (2011). Hybrid deflection prediction for machining thin-wall titanium alloy aerospace component, Ph.D. Thesis, School of Aerospace, Mechanical and Manufacturing Engineering, RMIT University, Melbourne, Australia. 